
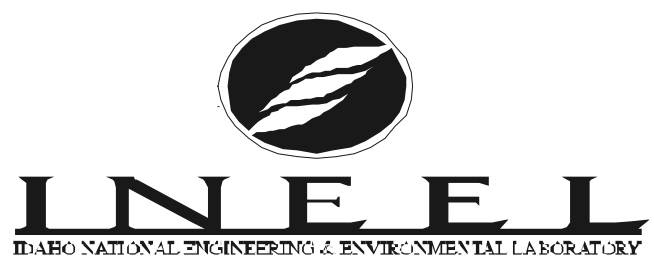

TIAHO SATTONAL FNGIATEPTNG \& EIVTRONTENTAI LA BORATORY

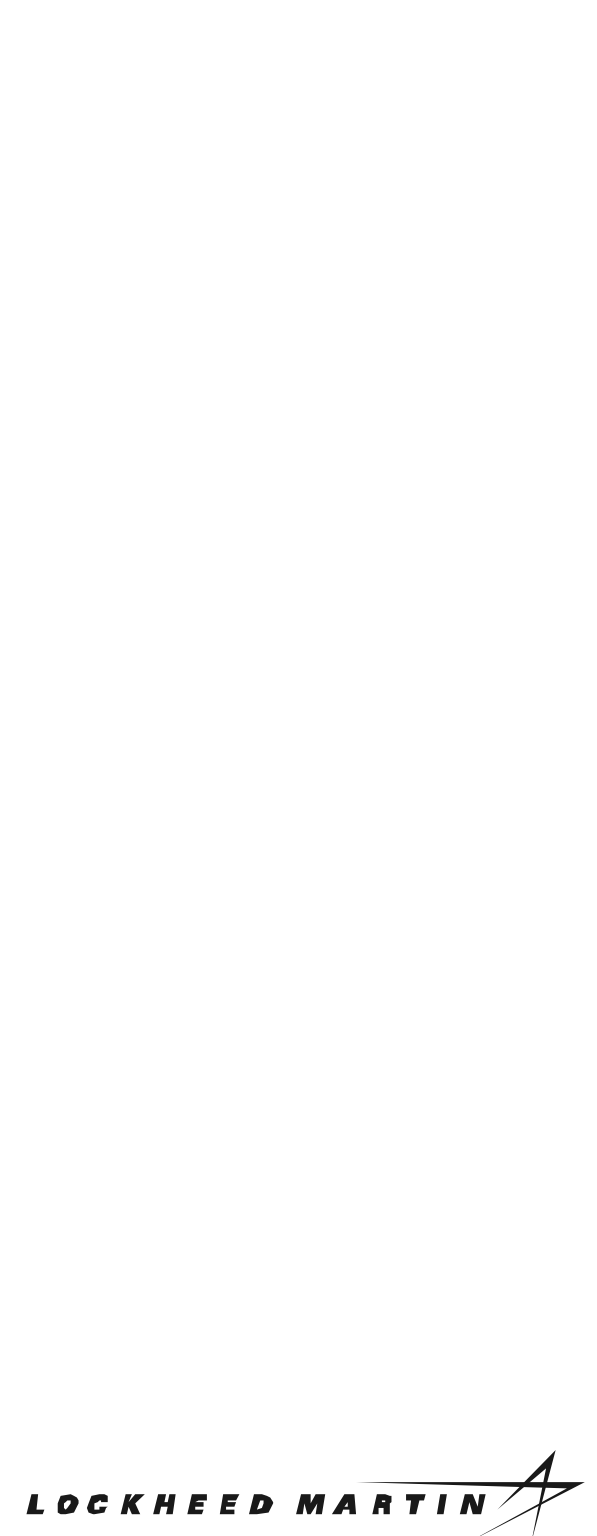

LOCKHEED MA ATIN

\section{Implementing Systems Engineering on a CERCLA Project}

G. A. Beitel

June 6, 1999 - June 10, 1999

$9^{\text {th }}$ Annual International Symposium of the International Council on Systems Engineering (INCOSE)

This is a preprint of a paper intended for publication in a journal or proceedings. Since changes may be made before publication, this preprint should not be cited or reproduced without permission of the author.

This document was prepared as a account of work sponsored by an agency of the United States Government. Neither the United States Government nor any agency thereof, or any of their employees, makes any warranty, expressed or implied, or assumes any legal liability or responsibility for any third party's use, or the results of such use, of any information, apparatus, product or process disclosed in this report, or represents that its use by such third party would not infringe privately owned rights. The views expressed in this paper are not necessarily those of the U.S. Government or the sponsoring agency. 


\title{
Implementing Systems Engineering on a CERCLA Project
}

\author{
George A. Beitel \\ Lockheed Martin Idaho Technologies Company \\ P.O. Box 1625 \\ Idaho Falls, Idaho 83415-3634
}

\begin{abstract}
The Comprehensive Environmental Response, Compensation, and Liability Act (CERCLA), enacted in 1980, provides a regulatory and legal mechanism to reduce risks from prior disposal of hazardous and toxic chemicals. Regulations, Standards, and Guidelines have been published to further define the CERCLA Process. The OU 7-10 Staged Interim Action Project at the Idaho National Environmental and Engineering Laboratory (INEEL) is a CERCLA project working to remediate a pre-1970 disposal pit in which transuranic materials had been disposed. This paper analyzes the CERCLA process from a systems engineering perspective and describes how systems engineering is implemented on this project.
\end{abstract}

\section{INTRODUCTION}

In 1991, the United States Environmental Protection Agency (EPA), Region10; the State of Idaho Department of Health and Welfare; and the United States Department of Energy entered into an agreement, under a Federal Facility Agreement and Consent Order (FFACO) pursuant to CERCLA (Environmental 1991). An Action Plan that implements that agreement established a framework under which INEEL CERCLA projects are conducted (Department 1991).

The OU 7-10 Staged Interim Action Project at the INEEL is chartered to remediate a near-surface disposal unit, Pit 9, in which transuranic materials had been disposed from 1967-69. Remediation involves excavation, retrieval, sorting and segregation, treatment, and disposal of transuranic wastes in a geologic repository, as well as closure of the pit. The wastes include significant quantities of chlorinated solvents, which today would be subject to land disposal restrictions. Near surface disposal of wastes containing transuranic radionuclides in concentrations greater than $100 \mathrm{nCi} / \mathrm{g}$ was banned in 1970 . In 1987 , mixed wastes (i.e., those containing both radioactive and chemically hazardous components) became subject to regulations governing both the radioactive and chemically hazardous component. The primary motivation for remediating these wastes is that they were buried above the Snake River aquifer, one of the major aquifers in the United States. There is no nearterm concern since the aquifer lies $600 \mathrm{ft}$ below the disposal trench. There is long-term concern because of the long half-life of the transuranic wastes coupled with the presence of environmentally stable halogenated hydrocarbon solvents.

Pit 9 has been investigated for much of the past 20 years with respect to possible remediation. The Pit 9 experience will support decisions to remediate the remainder of nearby disposal sites at the INEEL's Radioactive Waste Management Complex subsurface disposal area. In 1993, a CERCLA Record of Decision (ROD) was signed, formally establishing the requirements for Pit 9 remediation (Idaho 1993). An attempt was made to have a private subcontractor implement the interim action prescribed in the ROD. After the subcontract effort failed the project was assumed by LMITCO. The effort is presently in the title design of a system to provide for limited excavation and retrieval. Concurrently, subsurface sampling and exploration are in progress.

Lockheed Martin Idaho Technologies Company (LMITCO) is the Managing and Operating contractor responsible for the INEEL Site. LMITCO won the INEEL contract in 1994 based, in part, with a commitment to implement systems engineering practices similar to those successfully employed in the defense and aerospace industries. LMITCO uses a process based on the six classic systems engineering functions: Requirements Analysis (includes Mission Analysis and Requirements Management), Functional Analysis, Synthesis (Design), Trades, Test and Verification, and Integration.

The OU 7-10 Staged Interim Action Project, hereinafter referred to as the Pit 9 Project, is subject to the FFACO, CERCLA, the regulations that implement CERCLA, and the National Oil and Hazardous Substances Pollution Contingency Plan. 
Although the CERCLA process was not developed as a systems engineered process, and does not use systems engineering terminology, it is a highly structured process which incorporates most of the classical systems engineering functions. This paper begins by showing the parallel between the CERCLA process and systems engineering. It then shows how systems engineering has been incorporated into the Pit 9 Project and discusses how systems engineering has benefited the project.

\section{THE CERCLA PROCESS}

Figure 1, from (Department 1991), depicts the CERCLA process, with primary focus on initial screening and scoping, Remedial Investigation/Feasibility Study (RI/FS), Record of Decision (ROD), post ROD actions, and interface control.

Screening and Scoping. Sites and Operable Units (OU) are initially identified through top-level screening processes. A site, if it is recognized as presenting a significant environmental hazard, is first placed on the National Priorities List (NPL).

Subsequent screening of individual units may result in a Notice of Significant Impact (NSI), and removal from the NPL. This prioritization leads to the identification of operable units subject to a remedial investigation. The top-level screening and scoping may be based on historical records providing evidence of a potentially hazardous site; this activity is comparable to a Mission Analysis. The selection of Pit 9 was based on 16 years experience with nearsurface disposal of similar wastes and 20 -some years of studies about how to address the problem.

RI/FS. The RI/FS process consists of a Remedial Investigation phase to collect data to better define the problem and conduct preliminary treatability studies that may identify possible treatment solutions. This is followed by a Feasibility Study. Based on the data collected in the remedial investigation, the feasibility study identifies applicable alternatives that could provide a solution, including the no-action alternative. These alternatives are evaluated against a standard set of nine (9) CERCLA Criteria.

- Overall protection of human health and the environment

- Compliance with applicable or relevant and appropriate requirements

- Stage acceptance

- Community acceptance

\footnotetext{
${ }^{1}$ The documents listed in italic type in this section are specified by the Action Plan (Environmental 1991) and are required project phases or documents.
}

- Long-term effectiveness and permanence

- Reduction of toxicity, mobility, or volume through treatment

- Short-term effectiveness

- Implementability

- Cost

Criterion 2, "Compliance with applicable or relevant and appropriate requirements (ARARs)" is also the vehicle by which regulatory requirements, including most performance requirements, are identified. The ARARs are first identified during the Feasibility Study and updated in the subsequent plans and design documents. Not shown in Figure 1, but integral to the CERCLA process, is the preparation of Data Quality Objectives (DQOs). DQOs detail the requirements for data collection, including a trace to project requirements, the measurement method, and number of samples to be collected.

Record of Decision. The results of the RI/FS process are documented in a Proposed Plan. The Proposed Plan is similar in content to a Conceptual Design and submitted to the regulatory agencies and the public for review and comment. A decision on which alternative will be implemented is made at the end of the public comment phase and documented in a Record of Decision (ROD).

Post-ROD Actions. Planning, design, and implementation of a system to carry out the remedial action follow the ROD. Necessary systems are then designed, built, and remedial action executed.

A Statement of Work defines the scope of work to be accomplished. A Remedial Design/Remedial Action Work Plan is then prepared. The Remedial Design (RD) Work Plan is comparable to a conceptual design. Remedial Design is comparable to detailed design at the $90 \%$ completion stage. The Remedial Action (RA) Work Plan is prepared after the $90 \%$ design and includes all of the peripherals required to plan for construction, final cost estimates, and operations schedules.

A Prefinal Inspection Report is prepared after construction and combines a system test/verification and Operational Readiness Review (a safety-based readiness review). Readiness to operate is documented in a Remedial Action Report. 


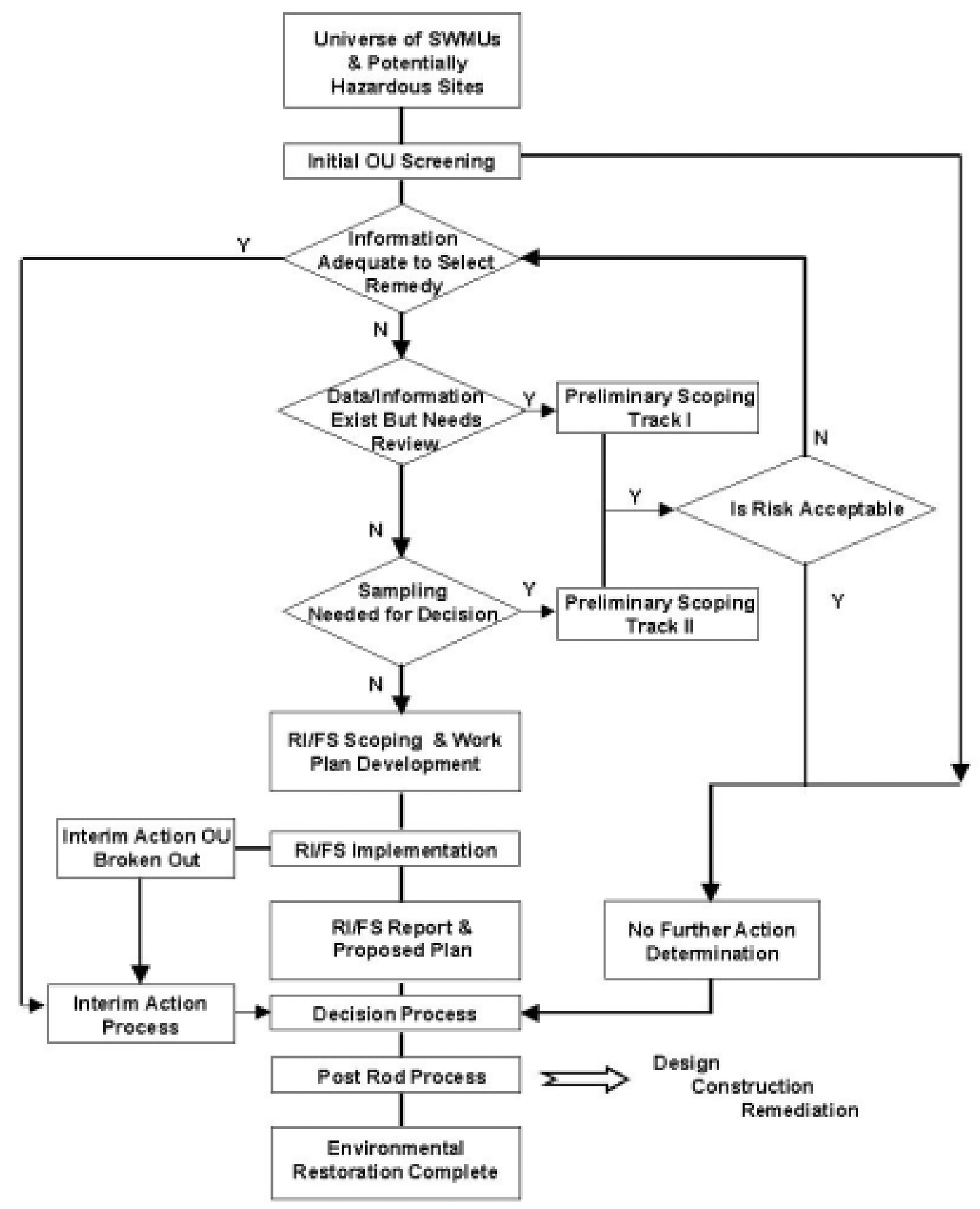

Figure 1. CERCLA Process Overview

$($ SWMUs $=$ Solid Waste Management Units) 
An Operation and Maintenance $(O \& M)$ Report is prepared at the completion of the operation and maintenance activities. The O\&M Report documents the remediation activities performed, verification (based on site monitoring) that the performance criteria (as defined in the ROD) have been met, and any final O\&M that may be required (e.g., on going and future environmental monitoring.)

Integration. Integration (which includes interface control) is addressed at many levels. CERCLA projects necessarily interface with the public. There are provisions throughout the process to interface with the public. The Draft ROD is subjected to a wide public review. A Community Relations Plan (CRP) is prepared and maintained throughout the project.

Another method of integration is the review process. The classical systems engineering process formally builds review into the system by specifying the system requirements review (SRR), system design review (SDR), preliminary design review (PDR), and critical design review (CDR.) The CERLA process uses the concept of "primary" and "secondary" documents to implement the review cycle. Primary and secondary documents are subject to review by the cognizant agencies. The primary and secondary documents for a particular project are proposed in the $R D / R A$ Statement of Work and are agreed to by the customer.

\section{SIMILARITIES AND DIFFERENCES BETWEEN THE CERCLA PROCESS AND SYSTEMS ENGINEERING}

The CERCLA process described above is compared with the LMITCO systems engineering process in Table 1. The CERCLA process has a structure that closely maps into the LMITCO systems engineering functions.

Table 1. The CERCLA Process

\begin{tabular}{|l|l|}
\hline $\begin{array}{c}\text { Systems Engineering } \\
\text { Functions }\end{array}$ & \multicolumn{1}{c|}{$\begin{array}{c}\text { CERCLA Documents } \\
\text { and Activities }\end{array}$} \\
\hline Requirements Analysis & $\begin{array}{l}\text { NPL, NSI, RI, DQOs, } \\
\text { ARARs, NCP }\end{array}$ \\
\hline Functional Analysis & \\
\hline Synthesis & FS, RD, RA, O\&M \\
\hline Trades & FS, ROD \\
\hline Test and Verification & $\begin{array}{l}\text { PFR, O\&M Report, } \\
\text { RAR, Treatability } \\
\text { Studies }\end{array}$ \\
\hline Integration & Reviews, CRP \\
\hline
\end{tabular}

Mission analysis is performed in placement of a site on the NPL, issuance of a Notice of Significant Impact, and completion of the Remedial Investigation. System performance requirements are defined in the ROD; environmental, technical, and administrative requirements are identified with ARARs, DQOs, and the National Contingency Plan, respectively.

Synthesis (i.e., design, construction, production) is accomplished at various stages of development through the Feasibility Study, Remedial Design, Remedial Action Work Plan, and the Operations and Maintenance Report. Alternatives analyses (Trades) are emphasized throughout the CERCLA process and specifically govern the ROD. Selection criteria are built into the regulations, and the Feasibility Study is instructed to use additional selection criteria.

CERCLA test and verification begin with the remedial investigation, which tests the premise that the selected site or operable unit is hazardous. Treatability studies are conducted at all levels to demonstrate that the proposed, selected, and designed technologies will function as required. The Prefinal Inspection Report tests the system, as built, to verify that it is safe to operate. The Remedial Action Report includes verification that the remedial action satisfied the primary objective of environmental risk reduction.

Integration is formally implemented as it relates to the review cycle and interfacing with the impacted community.

The significant differences between the CERCLA process and the LMITCO systems engineering process are: a) the absence of Requirements Management is absent, b) absence of functional analysis, and, c) the absence of systematic decision management below the ROD. In addition, the two systems use a totally different language, making the differences appear even greater.

The CERCLA process, as specified in the Action Plan focuses on the top-level documents to be delivered to the customer. The process to be implemented at the lower levels (how the remedial design will be conducted, for example) is left to the contractor. 


\section{SYSTEMS ENGINEERING ON THE PROJECT}

The OU 7-10 Staged Interim Action Project was initiated with a Scope of Work. The project was planned and begun based on a non-systems engineering, title design process in use by the Department of Energy for many years. Classic systems engineering products such as a System Requirements Document, Design Requirements Documents, a Systems Engineering Management Plan, Technical Performance Measures, and a Risk Management Plan had not been planned for. There were no provisions for requirements management, functional analyses, or structured technical baseline reviews. Systems engineers were added and the conversion to a systems engineered approach was undertaken after the project was initiated. At the time this document was written the project was nearing completion of preliminary $(30 \%)$ design.

The Pit 9 Project operates under the CERCLA process, as specified in the FFACO Action Plan (Department 1991). The primary and secondary documents continue to carry the CERCLA titles many of which were discussed above: RD/RA Work Plan, RA Report, Prefinal Inspection Report, RA Work Plan and O\&M Plan, and O\&M Report. Documents more readily identified as systems engineering documents are being incorporated into the project, and are discussed below.

The first action was to formalize the systems requirements in the System Requirements Document (SRD) and place these requirements under change control. The requirements were developed from the ROD and submitted to a formal System Requirements Review. Since the SRD was not recognized in the CERCLA process, and had not been identified as a primary document, it was initially submitted as an attachment to the Work Plan.

The next step was to place the requirements in a computerized Requirements Management database, RDD-100 (SLATE was initially used). With the SRD under change control, plans, designs, documents, etc., were required to be traceable to the system requirements. Technical Functional Requirements were prepared subordinate to the SRD. The next level of requirements were prepared following conceptual design and documented in the Design Requirements Document. Each of these documents was subjected to formal reviews. A detailed analysis of the ARARs was conducted in conjunction with the conceptual design. Data Quality Objectives have been prepared and included within the Work Plans.
The Pit 9 Project began operating under a configuration management plan that emphasized control of cost and schedule. The plan was judged inadequate to support formal systems engineering system. A new configuration management plan was the second major systems engineering document to be prepared. Under the new plan, the technical baseline was also placed under formal change control.

The third major activity was to implement formal trade studies on the project, first used during the pre-conceptual design stage. The trade studies greatly improved the information exchange between the project and the customers, providing an objective stage from which to discuss and evaluate alternatives. Alternative selection was documented in the trade study reports.

A Systems Engineering Management Plan (SEMP) should be the first document on a systems engineered project. Although it was the first document drafted by systems engineering, it was not issued for a year. In the interim, the systems engineers conducted their activities according to the draft SEMP. The SEMP specified a formal review process including the: System Requirements Review (SRR), System Design Review (SDR), Preliminary Design (Title I) Review (PDR), Critical Design (Title II) Review (CDR), Operational Readiness Review (ORR), and Functional Configuration Audit (FCA). The SEMP also established requirements for formal Technical Performance Measures (TPM), a Risk Management Plan (RMP), and Technical Baselines. The project implemented systems engineering principally through the use of integrated product teams (IPT) and cross product teams (CPT). The SEMP contains the IPT charters.

The IPTs and CPTs assure integration of the many components and contributors of the project. Currently, approximately 100 persons actively contribute to the project. Integration is also enhanced through the use of an Action Tracking System (ATS.) The ATS is a relational database that tracks issues, actions, positions, decisions, technical performance measures, risk elements, and documents that address or resolve these elements. 
The engineering design process follows the title-design system utilized by the Department of Energy for many years. Title design proceeds from Conceptual Design to Title 1, Title II and Title III design.

Functional analysis is used, but has played only a minor role on the project. $\mathrm{N}$-squared diagrams, a traditional systems engineering tool have been used only as incidental review tools. Two other systems engineering documents which would not otherwise have been used include a Test and Verification Matrix (TVM), included in the SRD, and a Master Test and Evaluation Plan (MTEP.)

The project systems engineering organization has prepared an Internet site to improve project communications. The Internet site carries project documents, the tracking system, IPT meeting minutes and other information. The Internet site is automatically available for all INEEL personnel. Offsite access is still limited, although extremely important because the two regulating agencies, the Idaho State Department of Environmental Quality and EPA Region 10 (both of which take a very active role in the Project) are located 300 and 800 miles away, respectively.

Table 2 compares the systems engineering process with the process now being implemented. The CERCLA documents and activities shown in Table 1 are required independent of the lower-level documents and processes. They are not repeated in Table 2.

Figure 2. Pit 9 Project SE Processes

\begin{tabular}{|l|l|}
\hline $\begin{array}{c}\text { Systems Engineering } \\
\text { Functions }\end{array}$ & $\begin{array}{c}\text { CERCLA Documents } \\
\text { and Activities }\end{array}$ \\
\hline $\begin{array}{l}\text { Requirements } \\
\text { Analysis }\end{array}$ & $\begin{array}{l}\text { Statement of Work } \\
\text { SEMP, SRD, TFR, } \\
\text { DRD, DQO, RDD-100, } \\
\text { ARARs, TPM }\end{array}$ \\
\hline Functional Analysis & N-Squared Diagrams \\
\hline Synthesis & CD, Title I, II and II \\
\hline Trades & $\begin{array}{l}\text { Formal Trade Studies, } \\
\text { Decision Database }\end{array}$ \\
\hline Test and Verification & $\begin{array}{l}\text { TVM, MTEP, DQOs, } \\
\text { Treatability Studies, } \\
\text { Staged Reviews: SRR, } \\
\text { SDR, PDR, CDR, ORR, } \\
\text { and FCA }\end{array}$ \\
\hline Integration & $\begin{array}{l}\text { IPTs, CPTs, CM, RMP, } \\
\text { ATS }\end{array}$ \\
\hline
\end{tabular}

It is still too early to judge overall contribution of systems engineering to controlling project cost and achieving the project objectives.
Implementation of systems engineering is still on the learning curve. Most of the project accepts the systems engineers and readily seek their support and assistance. The customers are pleased with the additional discipline that systems engineering has brought to the project. Change control of the technical baseline gives Project Management additional controls against technical changes without the rigor of a related cost and schedule analysis.

\section{SUMMARY}

The CERCLA Process provides a formalized framework within which to plan, design, and conduct a remedial action. It was established before the INEEL had any significant application of systems engineering. As a result, the CERCLA Process uses almost none of the systems engineering language. Nevertheless, there is nearly a one-to one mapping of the CERCLA project activities with the systems engineering functions. Noticeably missing is requirements managenent, and functional analysis, and the use of a decision methodology.

LMITCO has adapted a systems engineering process from the aerospace and defense industry for implementation at the INEEL. This process has now been used extensively on the Pit 9 Project for the past 12 months. Formal implementation of requirements management and decision processes has placed more rigor in the design process and provides better control over a project than the CERCLA process committed to by the FFACO. A stronger configuration management system has helped manage the technical changes. Finally, IPTs and CPTs have improved integreation, interface control, and project communication. 


\section{REFERENCES}

Idaho National Engineering and Environmental Laboratory, U.S. Department of Energy, U.S. Environmental Protection Agency, and the State of Idaho Department of Health and Welfare, Division of Environmental Quality, Declaration for Pit 9 at the Radioactive Waste Management Complex Subsurface Disposal Area, at the Idaho National Engineering Laboratory, Idaho Falls, ID, October, 1993.

U.S. Environmental Protection Agency, Region 10; the State of Idaho Department of Health and Welfare, and the United States Department of Energy, Federal Facility Agreement and Consent Order (FFA/CO), Administrative Docket Number 1088-0629-20, December 4, 1991.

U.S. Department of Energy, Action Plan for Implementation of the Federal Facility Agreement and Consent Order, 1991.

\section{BIOGRAPHY}

Dr. Beitel received his $\mathrm{PhD}$ from the University of Wisconsin, Madison, in Surface Physics, and has 25 years experience in Nuclear Materials and Nuclear Waste Management. He was employed for fourteen years at Hanford followed by eleven years at the Idaho National Engineering and Environmental Laboratory. Specific activities have included equipment test and design, treatability studies, safety analysis, planning, and program/project management. He is currently employed by Lockheed Martin Idaho Technologies company as a systems engineer for the OU 7-10 Staged Interim Action Project. In his spare time, he teaches Systems Engineering at the University of Idaho and Treatment of Radioactive Waste at the Idaho State University, and serves as a Thesis Advisor for Master's Degree topics such as Stabilization of Hazardous Wastes with Sulfur Polymer Cement, Evaluation of RCRA Waste Treatment and Storage Alternatives, Decision Analysis, and Cost Analysis.

\section{ACKNOWLEDGEMENT}

Work supported by the U.S. Department of Energy, Assistant Secretary for Environmental Management under DOE Idaho Operations Office, Contract DE-AC07-94ID13223. 